\title{
The Status of Emotional Competence among Muslim Teachers of Schools
}

\author{
Nagma Hungund $^{1}$ and V.S. Yadav ${ }^{2}$ \\ ${ }^{1}$ Department of Human Development and Family Studies, College of Rural Home Science, \\ Dharwad University of Agricultural Sciences Dharwad- 580005, Karnataka, India \\ ${ }^{2}$ Department of Psychology, College of agriculture, UAS, Dharwad, Karnataka, India
}

*Corresponding author

\begin{tabular}{|l|}
\hline K e y w o r d s \\
Adequate Depth of \\
Feeling (ADF), \\
Adequate \\
Expression and \\
Control of \\
Emotions (AEC) \\
\hline Article Info \\
\hline $\begin{array}{l}\text { Accepted: } \\
10 \text { October } 2019 \\
\text { Available Online: } \\
\text { 10 November } 2019\end{array}$ \\
\hline
\end{tabular}

Keywords

Adequate Depth of Feeling (ADF), Adequate

Expression and Control of Emotions (AEC)

Article Info

Accepted: Available Online: 10 November 2019

\section{Introduction}

Teaching is a profession in which majority of men and women are employed and it is a demanding job. The effectiveness of the educational system largely depends on active, resourceful and competent teachers. The teachers carryout the role of moulding the life of children effectively, but at the same time face stress as they are dealing with young children who are difficult to handle and have long lasting impact on the physical, mental and emotional health of school teachers. The Teachers have the responsibility of imparting education and being a role model for students. A teacher can perform his job well only when he/she is mentally sound and emotionally stable and can perform his duties in superior way. But unfortunately many teachers often experience negative emotions than positive ones. Negative emotions, such as, anxiety interferes in cognitive capacity for processing information, while positive emotions increase creative capacity for generating new ideas and 
ability to handle difficulties (Frederickson, 2001). Positive emotions in teachers increase health and well-being and level of adaptation. This is why the capacity to identify, understand and regulate both positive and negative emotions is indispensable in teaching profession.

In order to safeguard the teachers from harmful effects of stress, teachers should have greater skills of emotional competence that act as buffer and ensure well-being. Emotional competence (EC) is regarded as an affectrelated skill, which refers to the ability to understand, manage and express the social and emotional aspects of life in ways that enable one to coping with stressful and emotionally laden situations (Kotsou et al., 2011). Jennings and Greenberg (2009) reviewed the research studies and reported that socially and emotional competent teachers at the tone for strong and supportive relation between the teachers and students. Jennings (2011), stressed that social-emotional competent provides a necessary skills, base and dispositions that help the teachers to form supportive relationships with their students, effectively manage their classrooms and successfully implement social-emotional learning.

Emotional competence refers to one's ability to express or release one's inner feelings (emotions). It implies an ease around others and determines one's ability to effectively and successfully lead and express. It is described as the essential social skills to recognize, interpret, and respond constructively to emotions in one self and others. Emotional competence is the demonstration of selfefficacy in emotion-eliciting social transactions (Saarni, 1999). Self efficacy is used here to mean that the individual believes that she/he has the confidence and skills to achieve a desired outcome. 'Desired outcomes or goals' for the emotionally competent individual will, by definition, be integrated with his/her moral character (or personal integrity).

Bernard (2006) described emotional competence as the essential social skills to recognize, interpret, and respond constructively to emotions in one self and others. Individual learn the skills of emotional competence in social contexts and as a consequence. There will inevitably be situations in which individual respond with relative emotional incompetence, in spite of their best efforts to cope effectively.

The teachers functioning competently are characterized by the capacity to enjoy successes and suffering failures and building from both. An emotionally competent teacher learns and applies skills to manage stress, improve self-esteem, confidence, personal change, decision making, leadership, assertion, comfort and commitment which raise the quality of teaching, health and wellbeing (Nelson et al., 2005) and encompass mastery, maintenance and protective activities. Elias et al., (2009) argued that to be a socialemotional competent teacher mean not only to have a skill, but also to be aware of manage oneself and to be aware and manage the relationship with the others. He believed that the teachers who feel confident about their emotional skill will better recognize and understand student's emotions and their place in the student's behavior. There are several factors that significantly impact emotional competence such as age, gender, culture, religion, personality, education, socioeconomic status of family, quality of interrelationships, rural and urban background.

Historically, the role of religion has generally been accepted as an important component of the emotional competence. The findings of Abril et al., (2007) revealed that high frequencies of psychiatric morbidity were 
significantly differ in religious group and associated with their religious values. Similarly, Nesami et al., (2015) concluded that there is a direct correlation between positive religious coping and emotional intelligence. So strengthening religious coping was differing and can promote emotional intelligence that is one component of mental health.

Studies have supported the emotional competence significantly vary between the male and the female. Recent studies shown that there was significant difference in the mean scores on emotional competence with regard to sex, area, socio-economic status and (Shah, 2006). Similarly, McRae et al., (2008) proved that men respond better to cognitive regulation due to greater use of automatic emotion regulation. On the other hand, women use positive emotions during reappraising negative emotions more than men and Kumar et al., (2012) findings suggested that the levels of emotional intelligence among the lecturers improved with gender, teaching experience, grade and education where as age and prior working were not contributing factors.

Paliwal and Badola (2011) found that highest adequate depth of feeling (ADF) was found in the females from rural locality, adequate expression and control and function with emotion in the females from urban locality and enhancement of positive emotions in males of urban locality. Correspondingly, Madankar (2012) found that urban and rural teachers do not differ significantly on emotional competence. There are few studies on emotional competence in relation to Muslim religion, gender and locality, hence, the present study was undertaken with the objectives to assess the level of emotional competence of Muslim teachers of schools from urban and rural and to identify the differential effect of gender and locality on emotional competence of Muslim teachers of the schools. The emotional competence is an efficiency to deal effectively with several situations is a blend of many competencies (Coleman, 2007). Bharadwaj and Sharma (1995) have identified 5 components of emotional competence namely Adequate depth of feeling (ADF), Ability to function with emotions (AFE), Encouragement of positive emotions (EPE), Ability to cope with problem emotions (ACPE), Adequate expression and control of emotions (AEC).

\section{Adequate Depth of Feeling (ADF)}

Feeling in its broadest sense is any kind of process or experiencing (English and English, 1958) characterized by predominance of 'affect' and accessible emotions which lead to some kind of involvement to a great degree of the individual. A feeling of being confident or capable with all reality assumptions may be termed as adequate depth of feeling specifically associated with effective judgment and personality integration, which ensures vigorous participation in living.

\section{Adequate Expression and Control of Emotions (AEC)}

Emotional competence requires both an adequate expression and control which may be regarded as natural dynamic stability of an individual to express and control emotions spontaneously as demanded by the situation. Adequate expression and control of emotions refer to a tendency marked by adequate emotional expressiveness based on fulsome expression and control of emotions. Any form of inadequacy in either expression or control of emotions may lead to uncontrolled and disorganized emotionality.

\section{Ability to Function with Emotions (AFE)}

It is sometimes difficult to carry out even routine work when one finds himself face to 
face with a highly emotional situation. Emotional competence requires that the individual should develop a characteristic pattern of emotional reactivity which should not let him be influenced in his adequate mode of functioning that helps him in performing actions of daily routine properly.

\section{Ability to Cope with Problem Emotions (ACPE)}

Certain problem emotions play a destructive role and pose a potential damage to the life orientations of the individual's course of life. Therefore, emotional competence requires an understanding of the role of sensitivity and the detrimental effects of such emotions in the beginning and also a development of the ability to resist their harmful effects thereafter.

\section{Encouragement of Positive Emotions (EPE)}

The congenial growth of personality requires predominance of positive emotions that show a constructive influence in the dynamics of behavior. The growing vitality and a feeling of wholeness with a continuous capacity for intellectual and spiritual growth are associated with an experience of positive emotions. The encouragement of positive emotions refers to the ability of the person to develop a predominance of positive emotions in the personality make-up to ensure a meaningful and fairly well integrated life.

\section{Material and methods}

The present study was conducted in rural and urban areas of Dharwad taluk. The population of the study consisted of the school teachers in the age range of 25-60 years. The list of lower and higher primary schools of Dharwad taluk was obtained from the BEO office. There were 307 schools in Dharwad taluk out of which 171 schools were in urban area and 136 schools were in rural area. The purposive sample of 60 Muslim teachers (30 male and 30 female) were selected from 23 schools from Dharwad and Hubli corporation area and 60 Muslim teachers (30 male and 30 female) were selected from 13 schools from rural area on the basis of criteria that a married teacher was to belong Muslim religion, having at least a child and with at least of 5 years of married life. The teachers were contacted personally/in group and were requested to spare some time for filling the schedule individually. The schedule consisted of back ground information and emotional competence scale (Bharadwaj and Sharma, 1995). The data were subjected to frequency, percentages and $\mathrm{t}$ - test to measure the differential effects of gender and locality on emotional competence in Muslim teachers of the schools.

\section{Results and Discussion}

The results of Table 1 depicted the status of the male and the female teachers on Adequate depth of feeling (ADF), Adequate Expression and Control of Emotions (AEC), Ability to Function with Emotions (AFE), Ability to Cope with Problem Emotions (ACPE), Encouragement of Positive Emotions (EPE) and Emotional Competence of the male and the female teachers working in urban and rural areas.

\section{Adequate Depth of Feeling (ADF)}

The results (Table 1) notified that, among the male teachers working in urban area, about 40 per cent, 27 per cent, 13 per cent, 10 per cent and 10 per cent were average, competent, highly incompetent, incompetent and highly competent in their emotional competence, respectively. These results justify that about 37 per cent of the teachers were efficient in their emotions management and 63 per cent of the teachers were not efficient in their emotions management. Correspondingly, among the female teachers, about 57 per cent, 
23 per cent, 17 per cent, and 3 per cent were average, incompetent, competent and highly incompetent in their emotional competence, respectively. These results connoted that about 17 per cent of the teachers were efficient and 83 per cent of the teachers were not efficient in Adequate Depth of Feeling (ADF). These results mean that about 37 per cent of the male and 17 per cent of the female teachers working in urban area developed a feeling of confident or capable with all reality and associated with effective judgment and personality integration which ensures vigorous participation in living.

Subsequently, among the male teachers working in rural area, about 63 per cent, 23 per cent, 7 per cent and 7 per cent of the teachers were average, incompetent, highly incompetent and competent in their emotional competence, respectively. These results indicated that only about 7 per cent of the teachers were efficient in their emotions management, but most of the teachers $(93 \%)$ were not efficient in their emotional competence. Correspondingly, among the female teachers working in rural area, about 73 per cent, 23 per cent and 3 per cent of the teachers were average, incompetent and competent in their emotional competence, respectively. These results justified that most of the teachers (97\%) were not efficient and few of the teachers (3\%) were efficient in Adequate Depth of Feeling (ADF). These results mean that about 7 per cent of the male and 3 per cent of the female teacher working in rural area were characterized predominance of being confident in feelings with all reality experiences and effective judgment in understanding emotions in their life process.

But the mean score of the male teachers was 52.36 and the female teachers was 51.70 with 0.237 t-value working in urban schools, correspondingly the mean score of the male teachers was 47.96 and the female teachers was 50.00 with 1.138 t-value (Table 2) working in rural area revealed that there was no significant difference between the male and the female teachers working in urban and rural areas on Adequate Depth of Feeling (ADF). Even though the $t$ analyses notified similarity in Adequate Depth of Feeling (ADF) among the male and the female teachers working in urban and rural areas but the analyses of status of Adequate Depth of Feeling (ADF) among the teachers of rural and urban justified that 63 per cent and 93 per cent of the male teachers and 83 per cent and 97 per cent of the female teachers were need to develop competent level of $\mathrm{ADF}$, respectively.

\section{Adequate Expression and Control of Emotions (AEC)}

The results (Table 1) expressed that, among the male teachers working in urban area, about 60 per cent, 23 per cent, 10 per cent and 7 per cent of the teachers were average, highly incompetent, incompetent and competent in their emotional competence, respectively. These results revealed that about 7 per cent of the teachers were efficient in their emotions management and 93 per cent of the teachers were not efficient in their emotions management.

Correspondingly, among the female teachers, about 50 per cent, 30 per cent, 10 per cent, and 7 per cent and 3 per cent were incompetent, average, highly incompetent, competent and highly competent in their emotional competence, respectively. These results connoted that about 10 per cent of the teachers were efficient and 90 per cent of the teachers were not efficient in Adequate Expression and Control of Emotions (AEC). These results means that about 10 per cent of the female and only 7 per cent of the male teacher working in urban area were having a natural dynamic stability to express and control emotions spontaneously as demanded by the situation. Subsequently, among the male teachers 
working in rural area, about 47 per cent, 40 per cent and 13 per cent of the teachers were incompetent, average and highly incompetent in their emotional competence, respectively. These results indicated that none of the male teachers were efficient in managing of their emotions, but all most all the male teachers $(100 \%)$ were not efficient in their emotional competence. correspondingly, among the female teachers working in rural area, about 50 per cent, 47 per cent and 3 per cent of the teachers were average, incompetent and highly incompetent in their emotional competence, respectively. These results justified that none of the female teachers were capable of managing their emotions efficiently and 100 per cent of the teachers were not capable of managing their emotions efficiently. These results indicated that male and female teachers working in rural areas were not efficiently developed a tendency of adequate emotional expressiveness and control of emotions in their life, but they were just average in expressing and controlling of emotions.

But the mean score of the male teachers was 44.80 and the female teachers was 45.70 with 0.100 t-value working in urban schools, correspondingly the mean score of the male teachers was 41.13 and of the female teachers was 44.13 with 1.804 t-value (Table 2) working in rural area depicted that there was no significant difference between the male and the female teachers working in urban and rural areas on Adequate Expression and Control of Emotions (AEC). Even though the $\mathrm{t}$ analyses notified similarity in Adequate Expression and Control of Emotions (AEC) among the male and the female teachers working in urban and rural areas but their status analyses revealed that majority of the male teachers (93\%) and the female teachers $(90 \%)$ working in urban and all (100\%) the male and the female teachers working in rural were need to develop competent level of Adequate Expression and Control of Emotions (AEC).

\section{Ability to Function with Emotions (AFE)}

The results (Table 1) revealed that, among the male teachers working in urban area, about 43 per cent, 40 per cent, 10 per cent and 7 per cent were average, incompetent, competent and highly incompetent in their emotional competence, respectively. These results signify that about 10 per cent of the teachers were efficient in their emotions management and 90 per cent of the teachers were not efficient in their emotions management. Correspondingly, among the female teachers, about 43 per cent, 43 per cent, 7 per cent and 7 per cent were incompetent, average, incompetent, highly incompetent and competent in their emotional competence, respectively. These results connoted that about 7 per cent of the teachers were efficient and 93 per cent of the teachers were not efficient in their Ability to Function with Emotions (AFE). These results made it clear that about 10 per cent of the male and only 7 per cent of the female teachers working in urban area were having a characteristics pattern of emotional reactivity which help them to work in a highly emotional situation without any stress.

Subsequently, among the male teachers working in rural area, about 50 per cent, 47 per cent and 3 per cent of the teachers were incompetent, average and highly incompetent in their emotional competence, respectively. These results indicated that all most all $(100 \%)$ the male teachers from urban area were not efficient in their emotional competence. Subsequently, among the female teachers working in rural area, about 50 per cent and 50 per cent of the teachers were average and incompetent in their emotional competence, respectively. These results justified that none of the teachers were effective in their emotions management and all the teachers $(100 \%)$ were not efficient in their AFE. These results mean that about 47 
per cent of the male and half of (50\%) of the female teacher working in rural area were averagely characterized by performing actions of their daily routine properly and can find themselves to face with highly emotional situation.

But the mean score of the male teachers was 45.53 and the female teachers was 45.63 with 0.042 t-value working in urban schools, correspondingly, the mean score of the male teachers was 42.80 and the female teachers was 43.40 with 0.388 t-value (Table 2) working in rural area depicted that there was no significant difference between the male and the female working in urban and rural areas on Ability to Function with Emotions (AFE). Even though the $t$ analyses notified similarity in AFE among the male and the female teachers working in urban and rural areas but their status analyses justified that 90 per cent of male and 93 per cent of the female teachers working in urban and all most all (100\%) the male and the female teachers working in rural area were need to develop competent level of Ability to Function with Emotions (AFE).

\section{Ability to Cope with Problem Emotions (ACPE)}

The results (Table 1) expressed that, among the male teachers working in urban area, about 73 per cent, 13 per cent, 7 per cent and 7 per cent were average, incompetent, highly incompetent and competent in their emotional competence, respectively. These results justify that about 7 per cent of the teachers were efficient in their emotions management and 93 per cent of the teachers were not efficient in their Ability to Cope with Problem Emotions (ACPE). Correspondingly, among the female teachers, about 63 per cent, 20 per cent, and 7 per cent, 7 per cent and 3 per cent were average, incompetent, competent, highly incompetent and highly competent in their emotional competence, respectively. These results connoted that about 10 per cent of the teachers were efficient and 90 per cent of the teachers were not efficient in their Ability to Cope with Problem Emotions (ACPE).

These results mean that about 10 per cent of the female and 7 per cent of male teacher working in urban area developed an ability of understanding the role of sensitivity and detrimental effect of destructive emotions in their life.

Subsequently, among the male teachers working in rural area, about 60 per cent, 30 per cent and 10 per cent of the teachers were average, incompetent and highly incompetent in their emotional competence. These results revealed that all $(100 \%)$ male teachers from rural were not efficient in their emotional competence.

Correspondingly, among the female teachers working in rural area, about 67 per cent, 30 per cent and 3 per cent of the teachers were average, incompetent and highly incompetent in their emotional competence and 100 per cent of teachers from rural area were not efficient in Ability to Cope with Problem Emotions (ACPE). These results mean that about 60 per cent of the male and 67 per cent of the female teacher working in rural area were averagely developed a ability to cope with problem emotions and can resist their harmful effects to the life orientation of their course of life.

But the mean score of male teachers was 48.30 and the female teachers was 49.66 with $0.673 \mathrm{t}$ - value working in urban schools, correspondingly the mean score of the male teachers was 45.03 and the female teachers was 46.83 with 1.179 t-value (Table 2) working in rural area revealed that there was no significant difference between the male and the female working in urban and rural areas on ACPE. Even though the $t$ analyses notified 
Table.1 Status of emotional competence of Muslim teachers of schools working in urban and rural area

$\mathrm{N}=120$

\begin{tabular}{|c|c|c|c|c|c|c|c|c|c|c|c|}
\hline \multicolumn{12}{|c|}{ URBAN $(n=60)$} \\
\hline \multirow{2}{*}{$\begin{array}{l}\text { Sl. } \\
\text { No. }\end{array}$} & \multirow{2}{*}{$\begin{array}{c}\text { Components } \\
\text { of emotional } \\
\text { competence }\end{array}$} & \multicolumn{5}{|c|}{ Male $(n=30)$} & \multicolumn{5}{|c|}{ Female $(n=30)$} \\
\hline & & $\begin{array}{c}\text { Highly } \\
\text { incompetent }\end{array}$ & Incompetent & Average & Competent & $\begin{array}{c}\text { Highly } \\
\text { competent }\end{array}$ & $\begin{array}{c}\text { Highly } \\
\text { incompetent }\end{array}$ & Incompetent & Average & Competent & $\begin{array}{c}\text { Highly } \\
\text { competent }\end{array}$ \\
\hline 1 & ADF & $\begin{array}{c}04 \\
(13.33)\end{array}$ & $\begin{array}{c}03 \\
(10.00)\end{array}$ & $\begin{array}{c}12 \\
(40.00)\end{array}$ & $\begin{array}{c}08 \\
(26.66)\end{array}$ & $\begin{array}{c}03 \\
(10.00)\end{array}$ & $\begin{array}{c}01 \\
(3.33)\end{array}$ & $\begin{array}{c}07 \\
(23.33)\end{array}$ & $\begin{array}{c}17 \\
(56.66)\end{array}$ & $\begin{array}{c}05 \\
(16.66)\end{array}$ & - \\
\hline 2 & AEC & $\begin{array}{c}07 \\
(23.33)\end{array}$ & $\begin{array}{c}03 \\
(10.00)\end{array}$ & $\begin{array}{c}18 \\
(60.00)\end{array}$ & $\begin{array}{c}02 \\
(6.66)\end{array}$ & - & $\begin{array}{c}03 \\
(10.00)\end{array}$ & $\begin{array}{c}15 \\
(50.00)\end{array}$ & $\begin{array}{c}09 \\
(30.00)\end{array}$ & $\begin{array}{c}02 \\
(6.66)\end{array}$ & $\begin{array}{c}01 \\
(3.33)\end{array}$ \\
\hline 3 & AFE & $\begin{array}{c}02 \\
(6.66)\end{array}$ & $\begin{array}{c}12 \\
(40.00)\end{array}$ & $\begin{array}{c}13 \\
(43.33)\end{array}$ & $\begin{array}{c}03 \\
(10.00)\end{array}$ & - & $\begin{array}{c}02 \\
(6.66)\end{array}$ & $\begin{array}{c}13 \\
(43.33)\end{array}$ & $\begin{array}{c}13 \\
(43.33)\end{array}$ & $\begin{array}{c}02 \\
(6.66)\end{array}$ & - \\
\hline 4 & ACPE & $\begin{array}{c}02 \\
(6.66)\end{array}$ & $\begin{array}{c}04 \\
(13.33)\end{array}$ & $\begin{array}{c}22 \\
(73.33)\end{array}$ & $\begin{array}{c}02 \\
(6.66)\end{array}$ & - & $\begin{array}{c}02 \\
(6.66)\end{array}$ & $\begin{array}{c}06 \\
(20.00)\end{array}$ & $\begin{array}{c}19 \\
(63.33)\end{array}$ & $\begin{array}{c}02 \\
(6.66)\end{array}$ & $\begin{array}{c}01 \\
(3.33)\end{array}$ \\
\hline 5 & EPE & - & $\begin{array}{c}10 \\
(33.33)\end{array}$ & $\begin{array}{c}11 \\
(36.66)\end{array}$ & $\begin{array}{c}07 \\
(23.33)\end{array}$ & $\begin{array}{c}02 \\
(6.66)\end{array}$ & $\begin{array}{c}01 \\
(3.33)\end{array}$ & $\begin{array}{c}08 \\
(26.66)\end{array}$ & $\begin{array}{c}10 \\
(33.33)\end{array}$ & $\begin{array}{c}09 \\
(30.00)\end{array}$ & $\begin{array}{c}02 \\
(6.66)\end{array}$ \\
\hline 6 & $\begin{array}{c}\text { Emotional } \\
\text { competence }\end{array}$ & $\begin{array}{c}02 \\
(6.66)\end{array}$ & $\begin{array}{c}04 \\
(13.33)\end{array}$ & $\begin{array}{c}19 \\
(63.33)\end{array}$ & $\begin{array}{c}05 \\
(16.66)\end{array}$ & - & - & $\begin{array}{c}11 \\
(36.66)\end{array}$ & $\begin{array}{c}10 \\
(33.33)\end{array}$ & $\begin{array}{c}09 \\
(30.00)\end{array}$ & - \\
\hline \multicolumn{12}{|c|}{ RURAL $(n=60)$} \\
\hline 1 & ADF & $\begin{array}{c}02 \\
(6.66)\end{array}$ & $\begin{array}{c}07 \\
(23.33)\end{array}$ & $\begin{array}{c}19 \\
(63.33)\end{array}$ & $\begin{array}{c}02 \\
(6.66)\end{array}$ & - & - & $\begin{array}{c}07 \\
(23.33)\end{array}$ & $\begin{array}{c}22 \\
(73.33)\end{array}$ & $\begin{array}{c}01 \\
(3.33)\end{array}$ & - \\
\hline 2 & AEC & $\begin{array}{c}04 \\
(13.33)\end{array}$ & $\begin{array}{c}14 \\
(46.66)\end{array}$ & $\begin{array}{c}12 \\
(40.00)\end{array}$ & - & - & $\begin{array}{c}01 \\
(3.33)\end{array}$ & $\begin{array}{c}14 \\
(46.66)\end{array}$ & $\begin{array}{c}15 \\
(50.00)\end{array}$ & - & - \\
\hline 3 & AFE & $\begin{array}{c}01 \\
(3.33)\end{array}$ & $\begin{array}{c}15 \\
(50.00)\end{array}$ & $\begin{array}{c}14 \\
(46.66)\end{array}$ & - & - & - & $\begin{array}{c}15 \\
(50.00)\end{array}$ & $\begin{array}{c}15 \\
(50.00)\end{array}$ & - & - \\
\hline 4 & ACPE & $\begin{array}{c}03 \\
(10.00)\end{array}$ & $\begin{array}{c}09 \\
(30.00)\end{array}$ & $\begin{array}{c}18 \\
(60.00)\end{array}$ & - & - & $\begin{array}{c}01 \\
(3.33)\end{array}$ & $\begin{array}{c}09 \\
(30.00)\end{array}$ & $\begin{array}{c}20 \\
(66.66)\end{array}$ & - & - \\
\hline 5 & EPE & $\begin{array}{c}02 \\
(6.66)\end{array}$ & $\begin{array}{c}19 \\
(63.33)\end{array}$ & $\begin{array}{c}07 \\
(23.33)\end{array}$ & $\begin{array}{c}01 \\
(3.33)\end{array}$ & $\begin{array}{c}01 \\
(3.33)\end{array}$ & $\begin{array}{c}01 \\
(3.33)\end{array}$ & $\begin{array}{c}17 \\
(56.66)\end{array}$ & $\begin{array}{c}11 \\
(36.66)\end{array}$ & $\begin{array}{c}01 \\
(3.33)\end{array}$ & - \\
\hline 6 & $\begin{array}{c}\text { Emotional } \\
\text { competence }\end{array}$ & $\begin{array}{c}\text { 01 } \\
(3.33)\end{array}$ & $\begin{array}{c}14 \\
(46.66)\end{array}$ & $\begin{array}{c}15 \\
(\mathbf{5 0 . 0 0})\end{array}$ & - & - & - & $\begin{array}{c}12 \\
(40.00)\end{array}$ & $\begin{array}{c}17 \\
(56.66)\end{array}$ & $\begin{array}{c}01 \\
(3.33)\end{array}$ & - \\
\hline
\end{tabular}

Figure in parentheses indicates percentage

ADF - Adequate depth of feeling, AFE- Ability to function with emotions, EPE- Encouragement of positive emotions,

ACPE - Ability to cope with problem emotions, AEC- Adequate expression and control of emotions 
Table.2 Comparison between gender for Muslim teachers of schools working in urban and rural area on emotional competence

\begin{tabular}{|c|c|c|c|c|c|c|c|}
\hline \multirow{2}{*}{\multicolumn{8}{|c|}{ MUSLIM TEACHERS }} \\
\hline & & & & & & & \\
\hline \multirow{3}{*}{$\begin{array}{l}\text { Sl. } \\
\text { No }\end{array}$} & \multirow{3}{*}{ Particulars } & \multirow{2}{*}{\multicolumn{2}{|c|}{$\begin{array}{c}\text { Urban }(n=60) \\
\text { Mean } \pm \text { SD }\end{array}$}} & \multirow{3}{*}{ t- value } & \multirow{2}{*}{\multicolumn{2}{|c|}{$\begin{array}{c}\text { Rural }(n=60) \\
\text { Mean } \pm \text { SD }\end{array}$}} & \multirow{3}{*}{ t- value } \\
\hline & & & & & & & \\
\hline & & Male & Female & & Male & Female & \\
\hline 1 & ADF & $\begin{array}{c}52.36 \pm \\
12.76\end{array}$ & $\begin{array}{l}51.70 \pm \\
8.67\end{array}$ & $0.237^{\mathrm{NS}}$ & $\begin{array}{c}47.96 \pm \\
7.96\end{array}$ & $\begin{array}{l}50.00 \pm \\
5.69\end{array}$ & $-1.138^{\mathrm{NS}}$ \\
\hline 2 & AEC & $\begin{array}{c}44.80 \pm \\
11.12\end{array}$ & $\begin{array}{l}45.06 \pm \\
9.46\end{array}$ & $-0.100^{\mathrm{NS}}$ & $\begin{array}{c}41.13 \pm \\
7.09\end{array}$ & $\begin{array}{c}44.13 \pm \\
5.71\end{array}$ & $-1.804^{\mathrm{NS}}$ \\
\hline 3 & AFE & $\begin{array}{l}45.53 \pm \\
8.45\end{array}$ & $\begin{array}{c}45.63 \pm \\
9.82\end{array}$ & $-0.042^{\mathrm{NS}}$ & $\begin{array}{c}42.80 \pm \\
6.56\end{array}$ & $\begin{array}{c}43.40 \pm \\
5.36\end{array}$ & $-0.388^{\mathrm{NS}}$ \\
\hline 4 & ACPE & $\begin{array}{c}48.30 \pm \\
6.93\end{array}$ & $\begin{array}{c}49.66 \pm \\
8.69\end{array}$ & $-0.673^{\mathrm{NS}}$ & $\begin{array}{c}45.03 \pm \\
6.14\end{array}$ & $\begin{array}{c}46.83 \pm \\
5.66\end{array}$ & $-1.179^{\mathrm{NS}}$ \\
\hline 5 & EPE & $\begin{array}{c}51.43 \pm \\
11.40\end{array}$ & $\begin{array}{c}43.06 \pm \\
11.86\end{array}$ & $-0.544^{\mathrm{NS}}$ & $\begin{array}{l}43.36 \pm \\
9.16\end{array}$ & $\begin{array}{c}44.06 \pm \\
8.27\end{array}$ & $-0.311^{\mathrm{NS}}$ \\
\hline 6 & $\begin{array}{r}\text { Emotional } \\
\text { competence }\end{array}$ & $\begin{array}{c}242.43 \pm \\
36.20\end{array}$ & $\begin{array}{c}245.13 \pm \\
40.23\end{array}$ & $-0.273^{\mathrm{NS}}$ & $\begin{array}{c}220.30 \pm \\
27.62\end{array}$ & $\begin{array}{c}228.43 \pm \\
25.37\end{array}$ & $-1.188^{\mathrm{NS}}$ \\
\hline
\end{tabular}

NS - Not Significant; ADF- Adequate depth of feeling, AFE- Ability to function with emotions, EPE-

Encouragement of positive emotions, ACPE- Ability to cope with problem emotions, AEC- Adequate expression and control of emotions

Table.3 Comparison between the teachers working in urban and rural area on emotional competence

$\mathrm{N}=120$

\begin{tabular}{|c|c|c|c|c|}
\hline \multirow{2}{*}{ Sl. No } & \multirow{2}{*}{ Particulars } & \multicolumn{2}{|c|}{ Mean \pm SD } & \multirow{2}{*}{ t- value } \\
\cline { 3 - 5 } & & Urban & Rural & $3.24^{* *}$ \\
\hline 1. & Emotional Competence & $243.78 \pm 37.97$ & $224.37 \pm 26.61$ & \\
\hline
\end{tabular}

**significance at 0.01 level

Similarity in Ability to Cope with Problem Emotions (ACPE) among the male and the female teachers working in urban and rural areas, but their status analyses justified that majority (93\%) the male and 90 per cent of the female teachers working in urban and 100 per cent of the male and the female teachers working in rural were need to develop competent level of Ability to Cope with Problem Emotions (ACPE).

\section{Encouragement of Positive Emotions (EPE)}

The results (Table 1) signifies that, among the male teachers working in urban area, about 37 per cent, 33 per cent, 23 per cent and 7 per cent were average, incompetent, competent and highly competent in their emotional competence, respectively. These results justify that about 33 per cent of the teachers were efficient in their emotions management and 67 per cent of the teachers were not efficient in their emotions management. Correspondingly, among the female teachers, about 33 per cent, 30 per cent, 27 per cent, 7 per cent and 3 per cent were average, competent, incompetent, highly competent and highly incompetent in their emotional competence, respectively. These results connoted that about 37 per cent of the teachers were efficient and 63 per cent 
of the teachers were not efficient in their EPE. These results mean that about 37 per cent of the female and only 30 per cent of the male teacher working in urban area were developed a predominance of positive emotions in their personality make-up and they ensure a meaningful life and fairly well integrated life.

Subsequently, among the male teachers working in rural area, about 63 per cent, 23 per cent, 6 per cent, 3 per cent and 3 per cent of the teachers were incompetent, average, highly incompetent, competent and highly incompetent in their emotional competence, respectively. These results indicated that majority $(93 \%)$ of the male teachers were not efficient and few of the teachers (7\%) were efficient in their emotional competence. Correspondingly, among the female teachers working in rural area, about 57 per cent, 37 per cent, 3 per cent and 3 per cent of the the teachers were incompetent, average, highly incompetent and competent in their emotional competence. These results justified that few of the teachers $(3 \%)$ were efficient and majority $(97 \%)$ of the teachers were not efficient in their emotions management. These results mean that 7 per cent of the male and 3 per cent of the female teachers working in rural area were experienced of feeling of wholeness and having a continuous capacity for intellectual and spiritual growth.

But the mean score of the male teachers was 51.43 and the female teachers was 43.06 with 0.544 t-value working in urban schools, correspondingly the mean score of the male teachers was 43.36 and the female teachers was 44.06 with 0.311 t-value (Table 2) working in rural area depicted that there was no significant difference between the male and the female teachers working in urban and rural areas on Encouragement of Positive Emotions (EPE). Even though the $\mathrm{t}$ analyses notified similarity in Encouragement of Positive Emotions (EPE) among the male and the female teachers working in urban and rural areas but their status analyses justified that majority the male teachers $(70 \%)$ and 63 per cent the female teachers working in urban and majority of the male (93\%) and 97 per cent of the female were need to develop competent level of Encouragement of Positive Emotions (EPE).

\section{Emotional competence}

The results (Table 1) notified that, among the male teachers working in urban area, about 63 per cent, 17 per cent, 13 per cent and 7 per cent were average, incompetent, competent and highly incompetent in their emotional competence, respectively. These results justify that about 17 per cent of the teachers were efficient in their emotions management and majority of 83 per cent of the teachers were not efficient in their emotions management. Correspondingly, among the female teachers, about 37 per cent, 33 per cent and 30 per cent were in competent, average and competent in their emotional competence, respectively. These results connoted that about 37 per cent of the teachers were efficient and 63 per cent of the teachers were not efficient in their emotions management. These results mean that about 30 per cent of the female and only 17 per cent of the male teacher working in urban area were competent in their emotional management.

Subsequently, among the male teachers working in rural area, about 50 per cent, 47 per cent, and 3 per cent of the teachers were average, incompetent, and highly incompetent in their emotional competence. These results indicated that all $(100 \%)$ the male teachers were not efficient in their emotional competence. Correspondingly, among the female teachers working in rural area, about 57 per cent, 40 per cent and 3 per cent of the teachers were average, incompetent and competent in their emotional competence, respectively. These results justified that few of the teachers $(3 \%)$ were efficient and majority 
$(97 \%)$ of the teachers were not efficient in their emotions management. These results mean that none of the male teachers were emotionally competent but, only 3 per cent of the female teachers working in rural area were emotionally competent.

But the mean score of the male teachers was 242.43 and the female teachers was 245.13 with $0.273 \mathrm{t}$-value working in urban schools, correspondingly the mean score of the male teachers was 220.30 and the female teachers was 228.43 with 1.188 t-value (Table 2) working in rural area depicted that there was no significant difference between the male and the female teachers working in urban and rural areas on emotional competence. Even though the $t$ analyses notified similarity in emotional competence among the male and the female teachers working in urban and rural areas, but, their status analyses justified that, majority of the male teachers (83\%) and 70 per cent of the female teachers working in urban and 100 per cent of the male and 97 per cent of the female teachers were need to develop emotional competence.

Table 3 signifies that the mean score of the urban teachers was higher (243.78) than the rural teachers (224.37) and t-value of 3.24 shows the significant difference between them on emotional competence.

Overall results clearly mean that, in urban area, Muslim male were higher than the female in Adequate depth of feeling (ADF), Ability to function with emotions (AFE), Encouragement of positive emotions (EPE), Ability to cope with problem emotions (ACPE), Adequate expression and control of emotions (AEC) and emotional competence (Table 1). These findings were in accordance with the findings of Bansibihari et al., (2007) indicated that men experience emotions more competently than women of the secondary school teacher. This may be that, men were expected to remain cool and control their emotions more effectively than women and did not involve in win-lose arguing or neither the male set to achieve their own at the cost of their partners. As female were more sensitive, anything or something will hurt them thus less stable in managing of emotions.

In rural area, Muslim male and the female teachers were more or less similar in Adequate depth of feeling (ADF), Ability to function with emotions (AFE), Encouragement of positive emotions (EPE), Ability to cope with problem emotions (ACPE), Adequate expression and control of emotions (AEC) and emotional competence (Table 1) and with respect to the comparison between gender (Table 2), both the male and the female Muslim school teachers working in urban and rural areas irrespective of their gender, were more or less similar in Adequate depth of feeling (ADF), Ability to function with emotions (AFE), Encouragement of positive emotions (EPE), Ability to cope with problem emotions (ACPE), Adequate expression and control of emotions (AEC) and emotional competence. It clearly means that, Muslim male and the female teachers from urban and rural area can manage and handle emotions in similar way and were similar in emotional competence. These results were supported by study conducted by Madankar (2012) who found that, urban and rural the male and the female teachers do not differ significantly in respect of emotional competence. Also the rural teachers do not differ significantly on emotional competence. The reason may be that, both the male and the female teachers living in urban and rural area, were in primary relationship with more or less similar socioeconomic conditions having higher level of cooperation and co-ordination in their day to day life.

In regard of differential effects of locality on emotional competence of Muslim teachers, 
urban teachers were higher than rural teachers on emotional competence. These results were supported by study conducted by Paliwal and Badola (2011) who conclude that, highest Adequate Depth of Feeling (ADF) was found in the females from rural locality, adequate expression and control and function with emotion in females from urban locality and enhancement of positive emotions in males of urban locality. The probable reason may be that emotional coping was differing from locality. Still cultural practices and rituals were strongly existing in rural areas than urban and it makes Muslim teachers differed from one another in their identification of resources. Still In rural area, Muslim teachers were living within the sacred opportunities that denied them form exploring of their knowledge to the practical circumstances and moreover the rural teachers have not acquired the level of knowledge and skills that necessary to effectively serve the students with multiple needs. But, the urban teachers were having very sophisticated adaptability and adjustability to their occupation than the rural teachers that make them practically fit in facing of difficult circumstances and make them emotionally stable.

On the whole, majority of the male $(83 \%)$ and the female $(70 \%)$ Muslim teachers working in urban area and all most all the male (100\%) and majority of the female (97\%) teachers working in rural area were not competent in emotional management. The Male and the female Muslim teachers were similar in their emotional competence irrespective of rural and urban area. But the teachers working in urban area were higher in their emotional competence compared to the teachers working in rural area.

\section{References}

Abril, O. M., Castillo, J. L., Fernandez, C. M., Jurado, D., Gurpegvir, M., Claret, P.L. and Vargas, R.G., 2007, Factors associated with psychiatric morbidity in Spanish school teachers. Occupational Med., 20(1): 115-126.

Bernard, N. E., 2006, It's time we teach social-emotional competence as well as we teach academic competence. Reading Writing Quarterly, 22: 103119.

Bansibihari, V., Pandit, K, Pathan, M. and Yunus, G., 2007, Emotional intelligence of secondary teachers. Edutracks, 17(2): 65-70.

Bharadwaj, R. and Sharma, H. C., 1995, Manual for the Scale of Emotional Competencies. Mapan Bal Nivas, Agra, pp. 26-29.

Elias, M., Zins, J., Weissberg, R., Frey, K., Greenberg, T., Haynes, N., Kessler, R., Schwab-Stone, M. And Shiver, T., 2009, Promoting social and emotional learning: Guidelines for educators. Association for supervision and curriculum development. Alexandria, pp. 121-129.

Jennings, P. A. and Greenberg, M. T., 2009, The pro-social classroom: teacher social and emotional competence in relation to child and classroom outcomes. Review of educational research, 79:491-525.

Jennings, P. A., 2011, Promoting teacher's social and emotional competences to support performance and reduce burnout. New York, 133-143.

Kotsou, A., Liang, Y. And Saroj R., 2011, Study of Teacher effectiveness and occupational Stress in relation to emotional intelligence among teacher at secondary stage. Journal of history and social sciences, 22(1).

Kumar, S. and Murthy, S., 2008, Stressors, strain and coping strategies among women managers. Oxford and IBH Publishing Co. Pvt. Ltd. New Delhi, 73-79. 
Kumar, V. V., Manju, M. and Maheshwa, N., 2012, Effect of Emotional Intelligence on the Achievement Motivation. Journal of the Indian Academy of Applied Psychology, 39(1): 74-81.

McRae, K., Ochsner, K. N., Mauss, I. B., Gabrieli, J. D. E. and Gross, J. J., 2008, Gender differences in emotion regulation: An study of cognitive reappraisal. Group Processes and Intergroup Relations, 11: 143-62.

Nelson, Darwin, B., Low, Gary, R., Nelson. and Kaye., 2005, The emotionally intelligent teacher: A transformative learning model, Academic Press. New York, PP. 126-131.

Nesami, M. B., Goudarzian, A. H., Zarei, H., Esameili, P., Pour, M. D. and Mirani,
H., 2015, The relationship between emotional intelligence with religious coping and general health of married students, 27: 412-416.

Paliwal, L. and Badoka S., 2011, Emotional competency of boys and girls senior secondary students of urban and Rural area from upper and lower financial status. Dept. of Education, Mathura.

Saarni, C., 1999, The development of emotional competence. New York: Guilford, PP. 88-132.

Shah, V. K., 2006, Emotional Intelligence of Upper Primary Students of Gujarat State in Relation to Certain Variables. Unpublished Ph.D Thesis, Sardar Patel University. Vidyanagar, Gujarat.

\section{How to cite this article:}

Nagma Hungund and Yadav, V.S. 2019. The Status of Emotional Competence among Muslim Teachers of Schools. Int.J.Curr.Microbiol.App.Sci. 8(11): 1179-1191.

doi: https://doi.org/10.20546/ijcmas.2019.811.139 